\title{
LIMITING WATER RESOURCES FOR AGRICULTURAL USES IN RANIA DISTRICT, SULAIMANI GOVERNORATE
}

\author{
Barham M. Salem, Akram O. Esmail, and Alwand T. Rashid \\ Dept. of Soil and Water, College of Agricultural Engineering Sciences University of Salahuddin - \\ Erbil, Kurdistan Regio -Iraq
}

(Accepted for Publication: October 21, 2019)

\begin{abstract}
This study was conducted during $19^{\text {th }}$ August, 2018 to $12^{\text {th }}$ February, 2019 in Rania district, Sulaimani governorate to classify the water of 24 springs, 25 wells and 3 rivers for agricultural purpose. The results indicated that all the studied water had good or excellent class for irrigation depending on global systems of irrigation. On the other hand, depending on USDA classification (1954) the water of $(44,5,2$ and 1$)$ locations had $\left(C_{2} S_{1}, C_{3} S_{1}, C_{4} S_{1}\right.$ and $\left.C_{4} S_{2}\right)$ classes for irrigation purpose respectively. While the waters of 49 and 3 locations had excellent and very satisfactory class for livestock and poultry uses respectively. Depending on dissolved oxygen (DO $\mathrm{mg} \mathrm{l}^{-1}$ ) value most of the studied water were suitable for fish culture, except the water of two locations were not suitable for all fish species due to low values of dissolved oxygen in these two locations which were 5.20 and $6.30 \mathrm{mg}$ oxygen per ml water.
\end{abstract}

KEYWORDS: Water classes, Agricultural uses, Dissolved Oxygen.

https://doi.org/10.26682/cajuod.2020.22.2.4

\section{INTRODUCTION}

W ater quality is of essential and significant importance because of its role to human health, aquatic life, ecological integrity and sustainable economic growth. Indeed, without good quality, water sustainable development and environmentally sound management of water resources will be meaningless.

Also, poor irrigation water quality has negative effects on crop productivity, crop product quality, and public health of consumers and farmers who come in direct contact with the irrigation water. The impact of water quality is measured the effect of the irrigation water on soil characteristics and crops (Etteieb et al., 2017).//I//The Water quality of any specific area or specific source can be assessed using water quality of any specific area or specific source can be assessed using physical, chemical and biological parameters. The values of these parameters are res ponsible in limiting the water quality for agricultural uses (Ayers and Westcot, 1985)Water resources in Kurdistan region are including surface water such as streams, rivers, lakes, groundwater like wells and springs and its crucial to determine the classes of all these water sources to be clear that the main water fit to use in a specific purpose like irrigation, human drinking, livestock and poultry watering.

Quality of irrigation water depends on or determined by its chemical composition and the conditions of use. All the waters, surface or sub-surface, contain soluble salts which increases the concentration of the soil solution upon irrigation (Husaain et al., 2010). Ayers and Westcot (1985) indicated that water quality depends on physical, chemical and biological characteristics which influence its suitability for a specific use.

All the mentioned investigations have been done depending on several global and local classifications which included different systems of water classifications such as (Richards's classification, 1954) (Deneen classification, 1954) (Wilcox classification, 1955) (Ayers and Westcot cassification, 1985).

\section{GROUNDWATER CLASSIFICATION FOR} AGRICULTURAL USES:

There are numerous systems for irrigation water classification such as:

1- Richards's classification (1954).

Richards (1954) classified irrigation water into 16 classes depending on electrical conductivity and sodium adsorption ratio (EC and SAR) as shown in table (1). 
Table (1): USDA water classes.

\begin{tabular}{lllll}
\hline & \multicolumn{4}{c}{ SAR =S } \\
$E C=C$ dS m $^{-1}$ & C1S1 & C1S2 & C1S3 & C1S4 \\
& C2S1 & C2S2 & C2S3 & C2S4 \\
& C3S1 & C3S2 & C3S3 & C3S4 \\
C4S1 & C4S2 & C4S3 & C4S4 \\
\hline
\end{tabular}

\section{2- Deneen classification (1954).}

The irrigation water was classified depending on salinity potential (SP) and soil permeability to three classes as reported by Deneen in the table (2).

Table (2): water classes depending on SP.

\begin{tabular}{lccc}
\hline \multirow{2}{*}{ Water quality } & \multicolumn{4}{c}{ Salinity potential $(\mathrm{SP})=\left(\mathrm{Cl}^{-1}+1 / 2 \mathrm{SO}_{4}{ }^{2-}\right)$ mmole $_{\mathrm{c}} \mathrm{I}^{-1}$} \\
\cline { 2 - 4 } & Low & Medium & High \\
\cline { 2 - 4 } & $<7$ & $<5$ & $<3$ \\
\hline Good & $7-15$ & $5-10$ & $3-5$ \\
\hline Moderate &
\end{tabular}

\section{3- Wilcox classification (1955):}

Depending on residual Sodium Carbonate $\left.(\mathrm{RSC})=\mathrm{CO}_{3}{ }^{2-}+\mathrm{HCO}_{3}{ }^{-}\right)-\left(\mathrm{Ca}^{+2}+\mathrm{Mg}\right)\left(\right.$ mmole $\left._{\mathrm{c}}{ }^{-1}\right)$, Wilcox (1955) classified the irrigation water into three classes table (3).

Table (3): Water classes depending on RSC.

\begin{tabular}{lc}
\hline Water class & \\
\cline { 2 - 2 } & \\
\hline 1-Probably safe & $<1.25$ \\
\hline 2- Marginal & $1.25-2.5$ \\
\hline 3- Unsuitable & $>2.5$ \\
\hline
\end{tabular}

\section{4-Todd classification (1966):} (4).

Todd (1966) classified irrigation water based on (TDS), chloride and sodium percent as shown in

Table (4): Water classes depending on TDS, $\mathrm{Cl}$, and $\mathrm{Na} \%$.

\begin{tabular}{lccc}
\hline Parameter & Suitable & Moderate & Doubtful \\
\hline TDS $(\mathrm{ppm})$ & 700 & 2000 & $>2000$ \\
\hline $\mathrm{Cl}(\mathrm{ppm})$ & 150 & 500 & $>500$ \\
\hline $\mathrm{Na} \%$ & 60 & $60-75$ & $>75$ \\
\hline
\end{tabular}

\section{5-Ayers and Westcot classification (1985) :}

Depended on EC, SAR other properties as shown in table (5) the irrigation water was classified into three classes according to (Ayers and Westcot, 1985). 
Table (5): Ayers and Westcot classification (1985).

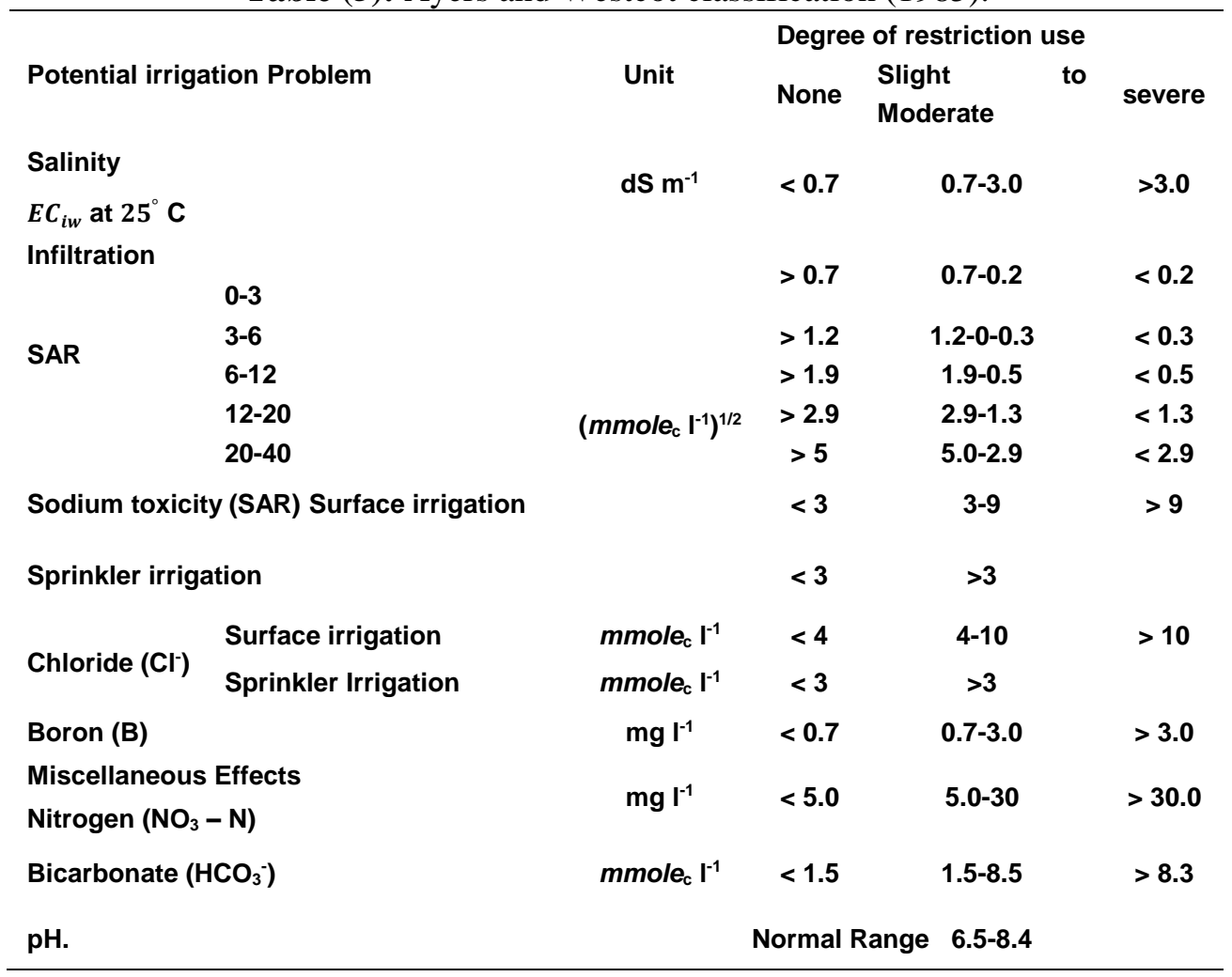

\section{6-Don classification (1995):}

Don (1995) classified irrigation water depending up on total salt content (TDS), EC, SAR, Na\% and $\mathrm{pH}$ to five classes as follow:

Table (6): Water classification depending on EC, TDS, Na\%, SAR, and $\mathrm{pH}$.

\begin{tabular}{lccccc}
\hline Water Quality & $\mathrm{EC}\left(\mathrm{dS} \mathrm{m}^{-1}\right)$ & $\mathrm{TDS}(\mathrm{ppm})$ & $\mathrm{Na} \%$ & $\mathrm{SAR}$ & $\mathrm{pH}$ \\
\hline Excellent & 0.25 & 175 & 20 & 3 & 6.5 \\
\hline Good & $0.25-0.75$ & $175-525$ & $20-4-0$ & $3-5$ & $6.5-6.8$ \\
\hline Permissible & $0.75-2.0$ & $525-1400$ & $40-60$ & $5-10$ & $6.8-7.0$ \\
\hline Doubtful & $2.0-3.0$ & $1400-2100$ & $60-80$ & $10-15$ & $7.0-8.0$ \\
\hline Unsuitable & $>3.0$ & $>2100$ & $>80$ & $>15$ & $>8.0$ \\
\hline
\end{tabular}

\section{Water classification for animal use:}

The water quality for livestock was classified by Altoviski (1962) as recorded in the table below:

Table (7): Water quality guide for the livestock uses or Altoviski classification.

\begin{tabular}{llllll}
\hline Parameters (ppm) & Very good & Good & Permissible & Can be used & Maximum limit \\
\hline $\mathrm{Ca}^{+2}$ & 350 & 700 & 800 & 900 & 1000 \\
\hline $\mathrm{Na}^{+}$ & 800 & 1500 & 2000 & 2500 & 4000 \\
\hline $\mathrm{Mg}^{+2}$ & 150 & 350 & 500 & 600 & 700 \\
\hline $\mathrm{SO}_{4}{ }^{-2}$ & 1000 & 2500 & 3000 & 4000 & 6000 \\
\hline $\mathrm{Cl}^{-}$ & 900 & 2000 & 3000 & 4000 & 6000 \\
\hline TDS & 3000 & 5000 & 7000 & 10000 & 15000 \\
\hline
\end{tabular}

Water quality guide for livestock and poultry uses was classified by Ayers and Westcott (1985 
Table (8): classification of water for animal uses (Ayers and Westcot,1985).

\begin{tabular}{|c|c|c|}
\hline Water (EC) dS m-1 & $\begin{array}{l}\text { Rating or } \\
\text { classes }\end{array}$ & Using \\
\hline$<1.5$ & Excellent & Usable for all classes of livestock and poultry \\
\hline $1.5-5.0$ & Very Satisfactory & $\begin{array}{l}\text { Usable for all classes of livestock and poultry. May cause } \\
\text { temporary diarrhea in livestock not accustomed to such water; } \\
\text { watery droppings in poultry. }\end{array}$ \\
\hline \multirow[t]{2}{*}{$5.0-8.0$} & $\begin{array}{l}\text { Satisfactory for } \\
\text { Livestock }\end{array}$ & $\begin{array}{l}\text { May cause temporary diarrhea or be refused at first by animals } \\
\text { not accustomed to such water. }\end{array}$ \\
\hline & Unfit for Poultry & $\begin{array}{l}\text { Often causes watery faeces, increased mortality and decreased } \\
\text { growth, especially in turkeys. }\end{array}$ \\
\hline \multirow[t]{2}{*}{$8.0-11.0$} & $\begin{array}{l}\text { Limited Use for } \\
\text { Livestock }\end{array}$ & $\begin{array}{l}\text { Usable with reasonable safety for dairy and beef cattle, sheep, } \\
\text { swine and horses. Avoid use for pregnant or lactating animals }\end{array}$ \\
\hline & Unfit for Poultry & Not acceptable for poultry. \\
\hline $11.0-16.0$ & Very Limited Use & $\begin{array}{l}\text { Unfit for poultry and probably unfit for swine. Considerable risk in } \\
\text { using for pregnant or lactating cows, horses or sheep, or for the } \\
\text { young of these species. In general, use should be avoided } \\
\text { although older ruminants, horses, poultry and swine may subsist } \\
\text { on waters such as these under certain conditions. }\end{array}$ \\
\hline$>16.0$ & $\begin{array}{l}\text { Not } \\
\text { Recommended }\end{array}$ & $\begin{array}{l}\text { Risks with such highly saline water are so great that it cannot be } \\
\text { recommended for use under any conditions. }\end{array}$ \\
\hline
\end{tabular}

The water quality for livestock was classified as mentioned by Ayers and Westcot (1985), which referred to upper limit of heavy metals and other ions as shown in table (9):

Table (9): Guidelines for livestock.

\begin{tabular}{cc}
\hline Parameter & Upper Limit $\left(\mathrm{mg} \mathrm{I}^{-1}\right)$ \\
\hline $\mathrm{Cd}$ & 0.05 \\
\hline $\mathrm{F}$ & 2.00 \\
\hline $\mathrm{Fe}$ & Not needed \\
\hline $\mathrm{Pb}$ & 0.10 \\
\hline $\mathrm{Mn}$ & 0.05 \\
\hline $\mathrm{NO}_{3}$ & 100 \\
\hline $\mathrm{NO}_{2}$ & 10 \\
\hline $\mathrm{Zn}$ & 24 \\
\hline
\end{tabular}

Many studies have been done at different locations in Kurdistan region on water quality which included both of surface water and ground water by Esmail, 1986 ,Dohuki ,1997, Mam Rasul 2000, Khwakarim et al., 2010, Esmail and Salih, 2014, Rajab, 2015, Bapir and Ali, 2016 and Albarwary et al., 2018). Also numerous studies have been done in Iraq by Alhashimi and Mustafa 2012 and Alamar, 2015.

ince there are little or no studies in Rania district about different water resources and their uses for different purpose for this reason this study was selected to classify the water of different resources (rivers, springs and wells ) for irrigation, livestock and poultry uses and fishing culture.

\section{MATERIALS AND METHODS}

The study was conducted in Rania district, Sulaimani, Iraqi Kurdistan region, which included 52 water sources ( 25 wells, 24 springs, and 3 rivers), the GPS reading of the studied locations were recorded in table (10). 
Table (10): GPS reading for selected locations.

\begin{tabular}{|c|c|c|c|c|}
\hline Samples & Location & $\begin{array}{l}\text { Elevation } \\
\text { (m) }\end{array}$ & $\mathbf{N}$ & E \\
\hline 1-River & Zey bchuk & 589 & $36^{\circ} 12^{\prime} 51.00^{\prime \prime}$ & $44^{\circ} 59^{\prime} 23.20^{\prime \prime}$ \\
\hline 2-River & Hizop & 526 & $36^{\circ} 10^{\prime} 18.80^{\prime \prime}$ & $44^{\circ} 41^{\prime} 12.40^{\prime \prime}$ \\
\hline 3-River & Shawre river & 768 & $36^{\circ} 21^{\prime} 16.90^{\prime \prime}$ & $44^{\circ} 46^{\prime} 37.00^{\prime \prime}$ \\
\hline \multicolumn{5}{|c|}{ Springs } \\
\hline 4-Spring & Qula-Rania & 594 & $36^{\circ} 15^{\prime} 24.80^{\prime \prime}$ & $44^{\circ} 53^{\prime} 09.00 "$ \\
\hline 5-Spring & Ganaw-Qurago & 527 & $36^{\circ} 12^{\prime} 24.06^{\prime \prime}$ & $44^{\circ} 56^{\prime} 16.30^{\prime \prime}$ \\
\hline 6-Spring & Qulga-chwarqurna & 533 & $36^{\circ} 12^{\prime} 02.50^{\prime \prime}$ & $44^{\circ} 52^{\prime} 49.70^{\prime \prime}$ \\
\hline 7-Spring & Darmanaw-qamtaran & 516 & $36^{\circ} 10^{\prime} 28.80^{\prime \prime}$ & $44^{\circ} 41^{\prime} 17.30^{\prime \prime}$ \\
\hline 8-Spring & Qula-kanymaran & 545 & $36^{\circ} 12^{\prime} 26.80^{\prime \prime}$ & $44^{\circ} 43^{\prime} 34.30^{\prime \prime}$ \\
\hline 9-Spring & Sarwchawa-sarwchawa & 537 & $36^{\circ} 16^{\prime} 32.40^{\prime \prime}$ & $44^{\circ} 45^{\prime} 19.80^{\prime \prime}$ \\
\hline 10-Spring & Kak hamza-plingan & 500 & $36^{\circ} 23^{\prime} 31.80^{\prime \prime}$ & $44^{\circ} 46^{\prime} 04.50^{\prime \prime}$ \\
\hline 11-Spring & Pira mlot & 927 & $36^{\circ} 23^{\prime} 40.20^{\prime \prime}$ & $44^{\circ} 46^{\prime} 33.30^{\prime \prime}$ \\
\hline 12-Spring & Qalat & 1015 & $36^{\circ} 23^{\prime} 45.30^{\prime \prime}$ & $44^{\circ} 47^{\prime} 17.30^{\prime \prime}$ \\
\hline 13-Spring & Dalwka & 1080 & $36^{\circ} 23^{\prime} 48.30^{\prime \prime}$ & $44^{\circ} 49^{\prime} 19.40^{\prime \prime}$ \\
\hline 14-Spring & Deman & 954 & $36^{\circ} 23^{\prime} 47.40^{\prime \prime}$ & $44^{\circ} 46^{\prime} 49.10^{\prime \prime}$ \\
\hline 15-Spring & Mamand axa-kawbin & 890 & $36^{\circ} 2421.00^{\prime \prime}$ & $44^{\circ} 45^{\prime} 06.00 "$ \\
\hline 16-Spring & Srushk-kawbin & 900 & $36^{\circ} 22^{\prime} 56.80^{\prime \prime}$ & $44^{\circ} 45^{\prime} 28.00^{\prime \prime}$ \\
\hline 17-Spring & Sarwchawa-Gulan & 1124 & $36^{\circ} 23^{\prime} 35.00^{\prime \prime}$ & $44^{\circ} 42^{\prime} 51.40^{\prime \prime}$ \\
\hline 18-Spring & Mamxalan & 831 & $36^{\circ} 23^{\prime} 42.70^{\prime \prime}$ & $44^{\circ} 42^{\prime} 28.20^{\prime \prime}$ \\
\hline 19-Spring & Sardke-daraban & 824 & $36^{\circ} 22^{\prime} 21.80^{\prime \prime}$ & $44^{\circ} 45^{\prime} 43.50^{\prime \prime}$ \\
\hline 20-Spring & Zurkan-dere & 633 & $36^{\circ} 16^{\prime} 16.00^{\prime \prime}$ & $44^{\circ} 48^{\prime} 07.20^{\prime \prime}$ \\
\hline 21-Spring & Sarukany-dere & 853 & $36^{\circ} 21^{\prime} 20.10^{\prime \prime}$ & $44^{\circ} 46^{\prime} 38.10^{\prime \prime}$ \\
\hline 22-Spring & Sarwchawa-qalasaiday sarw & 961 & $36^{\circ} 20^{\prime} 27.30^{\prime \prime}$ & $44^{\circ} 46^{\prime} 51.90^{\prime \prime}$ \\
\hline 23-Spring & Sarwchawa-nore & 1005 & $36^{\circ} 20^{\prime} 48.60^{\prime \prime}$ & $44^{\circ} 45^{\prime} 29.00^{\prime \prime}$ \\
\hline 24-Spring & Tawe-mirabag & 660 & $36^{\circ} 20^{\prime} 58.20^{\prime \prime}$ & $44^{\circ} 46^{\prime} 05.60^{\prime \prime}$ \\
\hline 25-Spring & Sarashkawtan & 1065 & $36^{\circ} 16^{\prime} 50.90^{\prime \prime}$ & $44^{\circ} 48^{\prime} 56.90^{\prime \prime}$ \\
\hline 26-Spring & Kany bnaw & 800 & $36^{\circ} 20^{\prime} 11.20^{\prime \prime}$ & $44^{\circ} 47^{\prime} 26.70^{\prime \prime}$ \\
\hline 27-Spring & Luse spring-topawa & 542 & $36^{\circ} 12^{\prime} 33.20^{\prime \prime}$ & $44^{\circ} 46^{\prime} 40.10^{\prime \prime}$ \\
\hline \multicolumn{5}{|c|}{ Wells } \\
\hline 28-Well & Qurago & 519 & $36^{\circ} 13^{\prime} 09.50^{\prime \prime}$ & $44^{\circ} 56^{\prime} 46.40 "$ \\
\hline 29-Well & Boskin 1 & 513 & $36^{\circ} 13^{\prime} 28.00^{\prime \prime}$ & $44^{\circ} 55^{\prime} 22.60^{\prime \prime}$ \\
\hline 30-Well & Boskin 2 & 529 & $36^{\circ} 13^{\prime} 24.70^{\prime \prime}$ & $44^{\circ} 54^{\prime} 47.20^{\prime \prime}$ \\
\hline 31-Well & Chwarqurna & 535 & $36^{\circ} 11^{\prime} 03.40^{\prime \prime}$ & $44^{\circ} 50^{\prime} 42.60^{\prime \prime}$ \\
\hline 32-Well & Hizop 1 & 552 & $36^{\circ} 10^{\prime} 28.40^{\prime \prime}$ & $44^{\circ} 41^{\prime} 17.90^{\prime \prime}$ \\
\hline 33-Well & Hizop 2 & 564 & $36^{\circ} 10^{\prime} 29.20^{\prime \prime}$ & $44^{\circ} 41^{\prime} 19.00^{\prime \prime}$ \\
\hline 34- Well & Klaw sur & 554 & $36^{\circ} 10^{\prime} 01.10^{\prime \prime}$ & $44^{\circ} 42^{\prime} 19.50 "$ \\
\hline 35-Well & Qamtaran & 549 & $36^{\circ} 10^{\prime} 01.50^{\prime \prime}$ & $44^{\circ} 44^{\prime} 41.40^{\prime \prime}$ \\
\hline 36-Well & Kany maran & 533 & $36^{\circ} 10^{\prime} 58.60^{\prime \prime}$ & $44^{\circ} 44^{\prime} 38.20^{\prime \prime}$ \\
\hline 37-Well & Qaraniaxa & 536 & $36^{\circ} 10^{\prime} 59.30 "$ & $44^{\circ} 44^{\prime} 29.20^{\prime \prime}$ \\
\hline 38-Well & Plingan & 522 & $36^{\circ} 12^{\prime} 15.80^{\prime \prime}$ & $44^{\circ} 45^{\prime} 56.70^{\prime \prime}$ \\
\hline 39-Well & Kolin 1 & 550 & $36^{\circ} 13^{\prime} 31.00^{\prime \prime}$ & $44^{\circ} 51^{\prime} 34.00^{\prime \prime}$ \\
\hline 40-Well & Kolin 2 & 533 & $36^{\circ} 13^{\prime} 25.00^{\prime \prime}$ & $44^{\circ} 50^{\prime} 30.00 "$ \\
\hline
\end{tabular}




\begin{tabular}{|c|c|c|c|c|}
\hline 41-Well & Garmkadal & 617 & $36^{\circ} 12^{\prime} 22.00^{\prime \prime}$ & $44^{\circ} 46^{\prime} 06.00^{\prime \prime}$ \\
\hline 42-Well & Shkarta & 634 & $36^{\circ} 20^{\prime} 39.40^{\prime \prime}$ & $44^{\circ} 42^{\prime} 30.90^{\prime \prime}$ \\
\hline 43-Well & Naqolan & 604 & $36^{\circ} 15^{\prime} 48.70^{\prime \prime}$ & $44^{\circ} 46^{\prime} 16.30^{\prime \prime}$ \\
\hline 44-Well & Hajiawa & 584 & $36^{\circ} 15^{\prime} 00.00^{\prime \prime}$ & $44^{\circ} 46^{\prime} 44.20^{\prime \prime}$ \\
\hline 45-Well & Rania & 637 & $36^{\circ} 15^{\prime} 58.80^{\prime \prime}$ & $44^{\circ} 50^{\prime} 40.50^{\prime \prime}$ \\
\hline 46-Well & Sarkapkan & 649 & $36^{\circ} 15^{\prime} 57.60^{\prime \prime}$ & $44^{\circ} 50^{\prime} 09.50^{\prime \prime}$ \\
\hline 47-Well & Rezena & 715 & $36^{\circ} 18^{\prime} 07.50^{\prime \prime}$ & $44^{\circ} 48^{\prime} 59.70^{\prime \prime}$ \\
\hline 48-Well & Pashkotal & 718 & $36^{\circ} 18^{\prime} 56.20^{\prime \prime}$ & $44^{\circ} 48^{\prime} 05.30^{\prime \prime}$ \\
\hline 49-Well & Nore & 821 & $36^{\circ} 21^{\prime} 05.70^{\prime \prime}$ & $44^{\circ} 46^{\prime} 09.60^{\prime \prime}$ \\
\hline 50-Well & Daraban & 846 & $36^{\circ} 22^{\prime} 05.05^{\prime \prime}$ & $44^{\circ} 45^{\prime} 34.09^{\prime \prime}$ \\
\hline 51-Well & Grjan 1 & 543 & $36^{\circ} 12^{\prime} 24.90^{\prime \prime}$ & $44^{\circ} 46^{\prime} 46.80^{\prime \prime}$ \\
\hline 52-Well & Grjan 2 & 549 & $36^{\circ} 12^{\prime} 33.30^{\prime \prime}$ & $44^{\circ} 46^{\prime} 40.20^{\prime \prime}$ \\
\hline
\end{tabular}

\section{WATER SAMPLING:}

Water samples were collected three times from $19^{\text {th }}$ August 2018 to $12^{\text {th }}$ January 2019 and in $1000 \mathrm{ml}$ disposable polyethylene

The main water analysis included $\mathrm{EC}, \mathrm{pH}$, concentration of $\mathrm{Ca}^{2+}, \mathrm{Mg}^{2+}, \mathrm{Na}^{+}, \mathrm{K}^{+}$, $\mathrm{Zn}^{2+}, \mathrm{Pb}, \mathrm{Cd}^{2+}, \mathrm{Mn}^{2+}, \mathrm{Fe}^{2+}, \mathrm{HCO}_{3}^{-}, \mathrm{CO}_{3}{ }^{2-}$ $, \mathrm{Cl}^{-}, \mathrm{SO}_{4}{ }^{2-} \cdot \mathrm{PO}_{4}{ }^{3-}$ and dissolved oxygen, which were determined according to APHA(1989) the range and the mean of the results were shown in table (11), While the mean concentration of them during $\mathrm{t}$

The results of water analyses were classified for agricultural uses depending on some global systems of water classification.

\section{RESULTS AND DISCUSSION}

Classification of water for irrigation purpose: The studied waters were classified according to some classifications as follow:

\section{Richards (1954) classification (USDA} classification):

Depending on USDA classification the water of (44, 5, 2 and 1) locations had $\left(\mathrm{C}_{2} \mathrm{~S}_{1}, \mathrm{C}_{3} \mathrm{~S}_{1}\right.$, $\mathrm{C}_{4} \mathrm{~S}_{1}$ and $\mathrm{C}_{4} \mathrm{~S}_{2}$ ) classes for irrigation purpose respectively. It means $84.62,9.62,3.84$ and 1.92 $\%$ of the studied waters had $\left(\mathrm{C}_{2} \mathrm{~S}_{1}, \mathrm{C}_{3} \mathrm{~S}_{1}, \mathrm{C}_{4} \mathrm{~S}_{1}\right.$ and $\mathrm{C}_{4} \mathrm{~S}_{2}$ ) class for irrigation (table ,11). These results indicated that the water of 49 locations were suitable for irrigation and the water of 1spring (Ganaw- Qurago spring) and 2 wells (Qurago and Pashkatol) were not good for irrigation due to high EC value more than 2.25 $\mathrm{dSm}^{-1}$ and moderate SAR value which ranged from $\quad 10 \quad$ to 18.

Table (11): shows the chemical properties of the studied water resources in Rania district.

\begin{tabular}{|c|c|c|c|c|c|c|c|c|c|}
\hline Water Properties & \multicolumn{3}{|c|}{ River } & \multicolumn{3}{|c|}{ Spring } & \multicolumn{3}{|c|}{ Well } \\
\hline & Min. & Max. & Mean & Min. & Max. & Mean & Min. & Max. & Mean \\
\hline pH & 7.88 & 7.94 & 7.91 & 6.88 & 7.55 & 7.26 & 6.75 & 7.55 & 7.22 \\
\hline Do $\left(\mathrm{mg} \mathrm{l}^{-1}\right)$ & 8.01 & 8.2 & 8.14 & 4.85 & 8.46 & 7.56 & 6.95 & 8.38 & 7.71 \\
\hline$E C\left(\mathrm{dSm}^{-1}\right)$ & 0.49 & 1.45 & 0.90 & 0.43 & 3.83 & 0.86 & 0.44 & 2.46 & 0.75 \\
\hline Mg & 0.86 & 3.5 & 2.31 & 1.02 & 7.93 & 2.41 & 0.92 & 3.49 & 1.84 \\
\hline $\mathrm{Ca}$ & 2.24 & 4.96 & 3.45 & 2.05 & 20.64 & 5.21 & 2.27 & 10.55 & 4.43 \\
\hline $\mathrm{Na}$ & 0.35 & 12.41 & 4.74 & 0.12 & 27.47 & 1.47 & 0.19 & 16.95 & 1.44 \\
\hline$\overline{0}$ & 0.07 & 0.42 & 0.21 & 0.03 & 3.55 & 0.23 & 0.04 & 0.72 & 0.12 \\
\hline $\mathrm{HCO}_{3}$ & 3.24 & 16.19 & 9.08 & 2.16 & 44.83 & 7.90 & 2.85 & 24.12 & 6.48 \\
\hline $\mathrm{CO}_{3}$ & 0.00 & 0.00 & 0.00 & 0.00 & 0.00 & 0.00 & 0.00 & 0.00 & 0.00 \\
\hline $\mathrm{SO}_{4}$ & 1.08 & 2.00 & 1.43 & 0.73 & 3.2 & 1.23 & 0.69 & 2.08 & 1.07 \\
\hline $\mathrm{Cl}$ & 0.03 & 0.18 & 0.08 & 0.01 & 0.84 & 0.07 & 0.03 & 0.28 & 0.081 \\
\hline $\mathrm{PO}_{4}\left(\mathrm{mg} \mathrm{l}^{-1}\right)$ & 0.00 & 5.81 & 2.90 & 0.00 & 6.22 & 1.43 & 0.00 & 4.67 & 1.2 \\
\hline SP & 0.29 & 0.68 & 0.43 & 0.40 & 1.64 & 0.38 & 0.23 & 0.79 & 0.35 \\
\hline RSC & 1.69 & 13.32 & 6.2 & 0.62 & 35.94 & 4.09 & 0.72 & 19.62 & 3.22 \\
\hline
\end{tabular}


Journal of University of Duhok., Vol. 22, No.2 (Agri. and Vet. Sciences), Pp, 2019 (special Issue)

The $3^{\text {rd }}$ international agricultural conference, $2^{\text {nd }}-3^{\text {rd }}$ October 2019 , Duhok

\begin{tabular}{|c|c|c|c|c|c|c|c|c|c|}
\hline $\operatorname{TDS}\left(\mathrm{mg} \mathrm{l}^{-1}\right)$ & 313.60 & 864 & 555.73 & 272 & 2320 & 546.27 & 278.4 & 1571.2 & 476.67 \\
\hline SAR & 0.24 & 10.36 & 4.08 & 0.12 & 12.95 & 0.79 & 0.18 & 11.3 & 1.02 \\
\hline $\mathrm{Na} \%$ & 4.00 & 67.00 & 34.00 & 1.00 & 56.00 & 7.00 & 4.00 & 64.00 & 12.00 \\
\hline $\mathrm{mg} \mathrm{l}^{-1}$ & $\mathrm{Nd}$ & Nd & Nd & Nd & $\mathbf{N d}$ & $\mathbf{N d}$ & Nd & $\mathbf{N d}$ & $\mathbf{N d}$ \\
\hline $\mathrm{Zn}$ & Nd & 0.001 & 0.0006 & Nd & 0.002 & 0.007 & $\mathrm{Nd}$ & 0.001 & 0.0004 \\
\hline Mn & $\mathrm{Nd}$ & 0.001 & 0.0006 & Nd & 0.002 & 0.007 & Nd & 0.001 & 0.0004 \\
\hline Cd & $\mathrm{Nd}$ & $\mathrm{Nd}$ & $\mathrm{Nd}$ & $\mathrm{Nd}$ & $\mathrm{Nd}$ & $\mathrm{Nd}$ & Nd & $\mathbf{N d}$ & Nd \\
\hline $\mathrm{NO}_{3}^{-}$ & 5 & 30 & 20 & 4 & 21 & 16 & 6 & 16 & 10 \\
\hline
\end{tabular}

\section{Doneen classification (1954):}

This classification depends on salinity potential (sp) and according to this parameter and the results in table (11) all the studied water have good class for high, moderate, and low permeable soils since the value of salinity potential was very low $\leq 1.64 \mathrm{mmolc}^{-1}$.

\section{Wilcox Classification (1954):}

The water for 8 locations number $(6,7,17,23$, $31,41,42$ and 52) have probably safe class because the value of residual sodium carbonate (RSC) of them was below $1.25 \mathrm{mmol}_{\mathrm{c}}{ }^{-1}$. whereas the water for locations number $(1,4,9,11,13,14,15,16,22,24,25$, $26,35,37,39,40,43,44,45,48$ and 49) were located within marginal class since the residual sodium carbonate (RSC )value of them was ranged between $(1.25-2.5)$ mmol $_{\mathrm{c}}{ }^{-1}$ and $\mathrm{d}$ the remain locations $(2,3,5,8,10,12,18,19,20$, 21, , 27, 28, 29, 30, 32, 33, 34, 36,38, 46, 47, 50 and 51) had unsuitable class because value of RSC for them were more than $2.50 \mathrm{mmol}_{\mathrm{c}} \mathrm{l}^{-1}$, (table ,11).

Ayers and Westcot (1985) classification: Depending on EC value the studied waters for the locations $(1,4,6,7,8,9,11,13,14,15,16$, $17,20,22,23,24,25,26,31,34,35,37,39,40$, $41,42,43,44,45,46,47,49,51$ and 52) were classified as non-saline water, or suitable for irrigation, while the water for locations number $(2,3,10,12,18,19,21,27,28,29,30,32,33$, $36,38,48$ and 50) were located within slight to moderate class and only water for location number (5) had sever class since it's EC value was more than $3 \mathrm{dS} \mathrm{m}^{-1}$. On the other hand depending on SAR value water for locations number 2 and 28 have slight to moderate degree of restriction for irrigation use, because SAR value of them was located between (3-9), whereas sample number (5) have sever restriction of use since its SAR value was more than 9, and all other water samples have no restriction use for irrigation.
Depending on $\mathrm{HCO}_{3}$ concentration the water samples of most locations had slight to moderate restriction use since the value of bicarbonate were ranged between (1.5-8.5) mmol $_{\mathrm{c}} \mathrm{l}^{-1}$ except the water for locations number $(2,5,12,18,28$, 32 and33) had moderate to severe restriction of use for irrigation because the value of $\mathrm{HCO}_{3}$ was more than $8.5 \mathrm{mmol}_{\mathrm{c}} \mathrm{l}^{-1}$ (Ayers and Westcot, 1985).

\section{Don classification (1995):}

Don (1995) classified irrigation water depending up on, EC, TDS, SAR, $\mathrm{Na} \%$ and $\mathrm{pH}$ to five classes as follow: According to Don (1995) classification. depending on EC values, the irrigation water for locations $(1,4,6,7,8,9,10$, $11,13,14,15,16,17,20,22,23,24,25,26,30$, $31,34,35,37,38,39,40,41,42,43,44,45,46$, $47,48,49,51$ and 52) had good class because the EC values were between $(0.25-0.75) \mathrm{dS} \mathrm{m}^{-1}$, however water for locations $(2,3,18,19,21,27$, 29, 32, 33, 36 and 50) had Permissible class, since their EC were more than $0.75 \mathrm{dS} \mathrm{m}^{-1}$ and less than $2 \mathrm{dS} \mathrm{m}^{-1}$, and water for locations (12 and 28) had a doubtful class because EC value

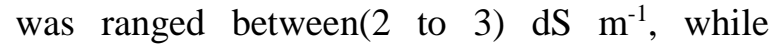
sample number 5 located within unsuitable class for irrigation because EC value of this water was more than $3 \mathrm{dS} \mathrm{m}^{-1}$.

Depending on total soluble salts the studied waters have different classes, water samples for locations $(1,3,4,6,7,8,9,10,11,13,14,15$, $16,17,20,22,23,24,25,26,29,30,31,34,35$, $37,38,39,40,41,42,43,44,45,46,47,48,49$, 51 and52 ) have good class for irrigation, since the TDS of these samples was located between (175-525) ppm, while the water for locations $(2$, $18,19,21,27,32,33,36$ and 50) were located within permissible class because the TDS value of them was ranged (from 525 to 1400) ppm, the samples number (12 and 28) were located within doubtful class, since the TDS value was ranged between (1400-2100) ppm, while the water for location number (5) had unsuitable 
class due to high TDS value ( more than 2100)ppm.

Relying on sodium percentage water samples of $(3,4,6,7,8,9,10,11,12,13,14,15,16,17,18$, $19,20,21,22,23,24,25,26,27,28,29,30,31$, $35,36,37,38,39,40,41,42,43,44,45,46,47$, $48,49,50,51$ and 52) had excellent class because $\mathrm{Na} \%$ value was less than $20 \%$, sample numbers $(1,32,33$ and 34$)$ had good class since $\mathrm{Na} \%$ was ranged from $(20-40) \%$, the water for location (5) has permissible class since the $\mathrm{Na} \%$ was located between (40-60)\%, and the water sample for locations (2 and 28) were located within doubtful class due to high sodium \% value $(60-80) \%$.

\section{Classification of water for animal uses:}

Depending on Ayers and Westcot (1985) the studied water for most of locations were excellent for poultry and livestock uses since their EC value was less than $1.50 \mathrm{dS} \mathrm{m}^{-1}$, except the water of Qurago-Ganaw spring and Qurago well which were very satisfactory for poultry and livestock uses because the EC value of them was between 1.50 to $5.0 \mathrm{dS} \mathrm{m}{ }^{-1}$.It means the water for all the studied locations were suitable for poultry and livestock uses or watering.

The water of the studied location were suitable for livestock uses depending on concentration of calcium, sodium, magnesium, Sulfate ,chloride and total dissolved salts according to Altoviski (1962) classification, since their values were less than $(300,800.150$, 1000,900 and 3000) ppm respectively as shown in table (11).

According to Ayers and Westcot (1985) the water of the studied locations were suitable for livestock uses since the concentration of the studied heavy metals and nitrate were very low in comparing with allowable concentration of them as shown in table (11 ). Since the concentration of the studied heavy metals and $\mathrm{NO}_{3}{ }^{-}$were very low in comparing with the allowable values by Ayers and Westcot (1985) as recorded in table (9).

Depending on Francis-Floyd (2003) most of the studied waters were suitable for fish culture since the dissolved oxygen of them was between (4.5 - more than 8) $\mathrm{mg} \mathrm{l}^{-1}$ which was suitable for most fish species. On the other hand the water for one spring (location number 12 or Daloka spring) and one well (location number 28 or Qurago well) were not suitable for fish culture since the TDS of them was more than 1000ppm or the $\mathrm{EC}$ value of them is more than $1.60 \mathrm{dS} \mathrm{m} \mathrm{m}^{-1}$

\section{CONCLUSION}

It appears from this investigation that the water of most of the studied locations (rivers, springs and wells) were suitable for irrigation, poultry, livestock uses in additional to fish culture.

\section{REFERENCE}

Alamar H. A. (2015). The Quality of Ground Water for Selected Area in South of Babylon Governorate/Iraq. Volume 3, Issue 4 PP 2936.

Al-Barwary, M..R., Meshabaz1, R. A., Hussein N. J. and Ali N. H. (2018). A Comparison of water quality between well and spring samples selected from Soran District, Northern Erbil Governorate, Kurdistan Region - Iraq. IOP Conf. Ser.: Mater. Sci. Eng. 454012062.

Alhashimi,S.A.M., and A.S. Mustafa. (2012). Prediction of water quality index for Euphrates river-Iraq. Pp 38-52.

Alhassan H. I., Muntasir, A. S. and Wesam M. 2018. Hydrochemical characterization of groundwater in Balad district, Salah Al-Din Governorate, Iraq. Journal of Groundwater Science and Engineering. Vol.6 NO.4.

Alobaidy, A. H. M. J., Abid, H. S. and Maulood, B. K. (2010). Application of water quality index for assessment of Dokan lake ecosystem, Kurdistan region, Iraq. journal of water resource and protection, 2, 792.

Altoviski, M. E. 1962. Handbook of hydrogeology, Gosgeolitzdat, Moscow, USSR. In Rissian.14.

APHA (American publication health association) (1989). Standard methods for the examination of water and waste water analysis. $17^{\text {th }}$ ed. Washinton.

Ayers, R. \& Westcot, D. (1985). Water quality for agriculture. Food and Agriculture Organization of the United Nations. Irrigation and drainage paper, 29.Rome, Italy ,FAO.

Babir, B. and Ali S.M. (2016). Evaluation of water quality of Koisanjaq basin, Erbil Governorate, Northern Iraq. Iraqi Journal of Science. Vol. 57(1): $194-208$.

Dohuki,M.S.S. (1997). Evaluation of some wells and springs water in Dohuk governorate for irrigation and drinking purpose. MSc. Thesis Salahaddin Univ., College of science, Dept. of Biology. 
Don, C. M. (1995). A Growes guide to water quality Univ. College station, Taxas Wimbaningrum, R., Arisoesilaningsih, E., Retnaningdyah, C., Indriyani, S. (2015). Assessment of surface water quality for irrigation purposes in Jember district, Indonesia. KnE Life Sciences, 2(1), 260-264.

Doneen, L. D. (1954). Salination of soil by salts in the irrigation water. Eos, Transactions American Geophysical Union, 35, 943-950.

Esmail, A. (1986). Limitation of some ground water suitability in Erbil plain for different uses. M. Sc. Thesis, Salahaddin Univ., Dept. of Soil science. In Arabic.

Esmail, A. O.. A. and Salih, H.O. (2014). The role of ion pairs and ion activity in classification of groundwater for irrigation in Erbil plain .Journal of Zankoi Sulaimani.Part A,Special Issue. 16:177-186.

Etteieb, S., Cherif, S. and Tarhouni, J. (2017). Hydrochemical assessment of water quality for irrigation: a case study of the Medjerda River in Tunisia. Appl. Water Sci. 7(1), 469480.

Francis-Floyd R. F. (2003). Dissolved oxygen for fish production.University of Florida ,Extension institute of food and agricultural science. Fact sheet, FA 27, Pp1-3.

Hussain, G., Alquwaizany, A. and Al-Zarah, A. (2010). Guidelines for irrigation water quality and water management in the Kingdom of Saudi Arabia: an overview. J Appl Sci, 10, 7996.

Khwakaram, A. I., Majid, S. N., Ahmed, Z. H. and Hama, N. Y. (2010). Application of Water Quality Index (WQI) as a possible indicator for agriculture purpose and assessing the ability of self purification process by Qalyasan Stream in Sulaimani City Iraqi Kurdistan Region (IKR). International Journal of Plant, Animal and Environmental Sciences, 5, 162173.

Mam Rasul, G.A. (2000). Study of water quality and its effect on nutrients availability for corn in Sulaimani region. .University of Sulaimani, Dept. of Soil and Water.

Rajab, K. S.. (2015). Classification of some Groundwater for irrigation purpose Depending on IWQI in Erbil plain-Iraqi Kurdistan region. M.Sc. thesis Salahddin University,Dept. of Soil and Water.

Richards, L. A. (1954). Diagnosis and improvement of saline and alkali soils. Agriculture hand book No. USDA Washington, 60.

Todd, D . K . (1966). Groundwater Hydrology, J. Wiley and Sons, New York.

Wilcox,L.V. (1955). Classification and use ofirrigation water.USDA.,Cir.20.

Appendix (1): The mean of some physiochemical properties of the studied water resources in Rania district during the hydrological year.

\begin{tabular}{cccccccccccc}
\hline Sample NO. & pH & EC $d S m^{1-}$ & DO $m g L^{1-}$ & $\mathrm{Mg}^{+2}$ & $\mathrm{Ca}^{+2}$ & $\mathrm{Na}^{+}$ & $\mathrm{K}^{+}$ & $\mathrm{HCO}_{3}{ }^{-}$ & $\mathrm{Cl}^{-}$ & $\mathrm{SO}_{4}{ }^{-2}$ & $\mathrm{CO}_{3}{ }^{-2}$ \\
1 & 7.84 & 0.51 & 8.01 & 0.87 & 2.24 & 1.45 & 0.07 & 3.25 & 0.04 & 1.21 & 0.00 \\
2 & 7.89 & 1.40 & 8.23 & 2.58 & 3.17 & 12.40 & 0.41 & 16.19 & 0.18 & 2.00 & 0.00 \\
3 & 7.83 & 0.77 & 8.38 & 3.50 & 4.96 & 0.35 & 0.14 & 7.81 & 0.02 & 1.08 & 0.00 \\
4 & 7.33 & 0.62 & 8.20 & 1.50 & 3.11 & 0.20 & 0.04 & 3.58 & 0.02 & 1.11 & 0.00 \\
5 & 7.26 & 3.61 & 5.07 & 4.67 & 13.24 & 27.45 & 3.53 & 44.87 & 0.80 & 3.19 & 0.00 \\
6 & 7.53 & 0.59 & 7.97 & 1.68 & 3.04 & 0.30 & 0.08 & 3.48 & 0.04 & 1.33 & 0.00 \\
7 & 7.41 & 0.52 & 8.32 & 1.03 & 2.59 & 0.28 & 0.07 & 2.88 & 0.06 & 0.93 & 0.00 \\
8 & 7.36 & 0.80 & 8.00 & 1.50 & 4.54 & 1.21 & 0.16 & 5.70 & 0.13 & 1.27 & 0.00 \\
9 & 7.34 & 0.69 & 8.34 & 1.75 & 4.46 & 0.31 & 0.06 & 5.10 & 0.04 & 1.35 & 0.00 \\
10 & 7.31 & 0.76 & 7.50 & 2.40 & 4.56 & 0.20 & 0.06 & 6.09 & 0.05 & 0.96 & 0.00 \\
11 & 7.40 & 0.70 & 8.33 & 2.24 & 3.95 & 0.19 & 0.05 & 5.20 & 0.04 & 1.16 & 0.00 \\
12 & 7.13 & 2.36 & 6.34 & 7.94 & 20.65 & 0.37 & 0.20 & 26.90 & 0.04 & 2.03 & 0.00 \\
13 & 7.51 & 0.64 & 8.38 & 2.27 & 3.35 & 0.18 & 0.05 & 4.53 & 0.06 & 1.25 & 0.00 \\
14 & 7.36 & 0.67 & 7.55 & 2.40 & 4.01 & 0.22 & 0.09 & 5.34 & 0.05 & 1.14 & 0.00 \\
15 & 7.53 & 0.64 & 8.56 & 2.22 & 3.48 & 0.14 & 0.05 & 4.95 & 0.02 & 0.89 & 0.00 \\
16 & 7.49 & 0.60 & 8.40 & 2.24 & 3.54 & 0.17 & 0.05 & 4.54 & 0.03 & 1.24 & 0.00 \\
17 & 7.57 & 0.44 & 8.47 & 1.04 & 2.05 & 0.12 & 0.04 & 2.17 & 0.03 & 1.01 & 0.00 \\
18 & 7.13 & 1.50 & 6.24 & 5.31 & 11.78 & 0.51 & 0.16 & 16.23 & 0.05 & 1.41 & 0.00 \\
19 & 7.28 & 0.95 & 6.87 & 3.22 & 5.53 & 0.57 & 0.22 & 8.52 & 0.07 & 0.91 & 0.00 \\
20 & 7.34 & 0.71 & 8.35 & 2.49 & 4.82 & 0.21 & 0.10 & 6.48 & 0.04 & 1.03 & 0.00 \\
21 & 7.25 & 0.85 & 7.32 & 2.61 & 5.73 & 0.24 & 0.10 & 7.42 & 0.04 & 1.19 & 0.00 \\
\hline
\end{tabular}


Journal of University of Duhok., Vol. 22, No.2 (Agri. and Vet. Sciences), Pp, 2019 (special Issue) The $3^{\text {rd }}$ international agricultural conference, $2^{\text {nd }}-3^{\text {rd }}$ October 2019 , Duhok

\begin{tabular}{|c|c|c|c|c|c|c|c|c|c|c|c|}
\hline 22 & 7.57 & 0.63 & 8.37 & 1.72 & 3.29 & 0.17 & 0.04 & 4.38 & 0.05 & 0.75 & 0.00 \\
\hline 23 & 7.59 & 0.52 & 8.25 & 1.11 & 2.23 & 0.15 & 0.04 & 2.32 & 0.04 & 1.01 & 0.00 \\
\hline 24 & 7.54 & 0.61 & 8.07 & 1.55 & 3.48 & 0.21 & 0.04 & 3.88 & 0.03 & 1.18 & 0.00 \\
\hline 25 & 7.51 & 0.57 & 8.39 & 1.46 & 2.74 & 0.17 & 0.04 & 3.60 & 0.04 & 0.73 & 0.00 \\
\hline 26 & 7.49 & 0.56 & 8.27 & 1.47 & 3.12 & 0.23 & 0.05 & 3.55 & 0.05 & 1.10 & 0.00 \\
\hline 27 & 7.31 & 0.90 & 7.93 & 2.25 & 5.97 & 1.51 & 0.10 & 8.22 & 0.17 & 1.23 & 0.00 \\
\hline 28 & 7.23 & 2.44 & 7.81 & 2.55 & 6.43 & 16.94 & 0.71 & 24.11 & 0.26 & 2.07 & 0.00 \\
\hline 29 & 7.33 & 0.87 & 8.14 & 2.02 & 5.24 & 1.44 & 0.10 & 7.23 & 0.13 & 1.09 & 0.00 \\
\hline 30 & 7.40 & 0.80 & 8.25 & 1.98 & 4.69 & 0.98 & 0.14 & 6.42 & 0.12 & 1.07 & 0.00 \\
\hline 31 & 7.60 & 0.49 & 8.45 & 1.49 & 2.29 & 0.25 & 0.09 & 2.87 & 0.05 & 0.99 & 0.00 \\
\hline 32 & 7.03 & 1.33 & 7.29 & 1.09 & 10.56 & 3.50 & 0.09 & 12.88 & 0.29 & 1.14 & 0.00 \\
\hline 33 & 7.1 & 1.17 & 7.38 & 1.37 & 7.41 & 3.01 & 0.09 & 10.37 & 0.23 & 1.03 & 0.00 \\
\hline 34 & 7.40 & 0.66 & 8.44 & 1.67 & 3.53 & 1.38 & 0.16 & 5.23 & 0.10 & 1.15 & 0.00 \\
\hline 35 & 7.52 & 0.51 & 8.04 & 1.02 & 3.23 & 0.25 & 0.05 & 3.49 & 0.05 & 0.91 & 0.00 \\
\hline 36 & 7.16 & 1.14 & 6.97 & 1.95 & 5.08 & 1.54 & 0.13 & 7.33 & 0.23 & 1.03 & 0.00 \\
\hline 37 & 7.28 & 0.74 & 7.68 & 2.07 & 4.25 & 0.40 & 0.07 & 5.50 & 0.07 & 1.11 & 0.00 \\
\hline 37 & 7.33 & 0.80 & 7.81 & 2.56 & 5.09 & 0.56 & 0.20 & 7.21 & 0.05 & 1.05 & 0.00 \\
\hline 39 & 7.49 & 0.53 & 7.48 & 1.11 & 2.85 & 0.24 & 0.08 & 3.27 & 0.05 & 0.89 & 0.00 \\
\hline 40 & 7.44 & 0.49 & 7.98 & 1.34 & 3.07 & 0.39 & 0.05 & 3.64 & 0.04 & 1.08 & 0.00 \\
\hline 41 & 7.58 & 0.49 & 7.58 & 1.23 & 2.82 & 0.19 & 0.06 & 2.97 & 0.04 & 0.98 & 0.00 \\
\hline 42 & 7.47 & 0.46 & 8.08 & 0.92 & 3.12 & 0.21 & 0.04 & 2.91 & 0.03 & 1.04 & 0.00 \\
\hline 43 & 7.33 & 0.63 & 8.06 & 1.54 & 3.95 & 0.24 & 0.06 & 4.32 & 0.06 & 1.21 & 0.00 \\
\hline 44 & 7.47 & 0.56 & 8.09 & 1.64 & 3.07 & 0.23 & 0.05 & 4.03 & 0.04 & 0.84 & 0.00 \\
\hline 45 & 7.43 & 0.64 & 8.21 & 2.02 & 4.09 & 0.28 & 0.09 & 5.18 & 0.06 & 1.13 & 0.00 \\
\hline 46 & 7.38 & 0.61 & 8.00 & 1.85 & 3.88 & 0.80 & 0.07 & 5.56 & 0.05 & 0.80 & 0.00 \\
\hline 47 & 7.36 & 0.71 & 8.11 & 2.30 & 4.67 & 0.35 & 0.10 & 6.11 & 0.06 & 1.10 & 0.00 \\
\hline 48 & 7.32 & 0.77 & 8.01 & 2.88 & 3.54 & 0.35 & 0.12 & 5.68 & 0.06 & 1.07 & 0.00 \\
\hline 49 & 7.28 & 0.71 & 8.08 & 2.09 & 4.30 & 0.43 & 0.10 & 5.57 & 0.08 & 1.15 & 0.00 \\
\hline 50 & 7.21 & 0.95 & 7.59 & 3.49 & 4.36 & 1.20 & 0.23 & 8.44 & 0.09 & 0.69 & 0.00 \\
\hline 51 & 7.54 & 0.73 & 8.16 & 2.13 & 5.12 & 0.39 & 0.07 & 6.33 & 0.06 & 1.14 & 0.00 \\
\hline 52 & 7.34 & 0.67 & 8.28 & 2.03 & 4.67 & 0.39 & 0.07 & 5.97 & 0.05 & 1.03 & 0.00 \\
\hline RLSD.001 $_{.01}$ & 0.11 & 0.23 & 1.02 & 0.67 & 1.85 & 0.44 & 0.05 & 2.30 & 0.06 & 0.39 & N.S \\
\hline
\end{tabular}

ديارى كردنى ههندىّ سه رجاوهى ئاو بوّ به كارهيّنانى كشتوكالى له رانيه \ياريّزكاى سليّمانى 


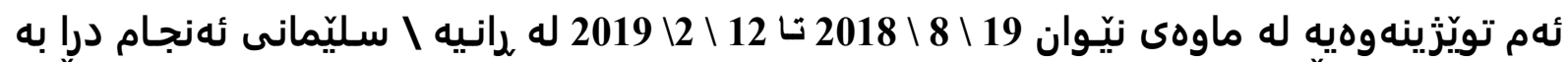

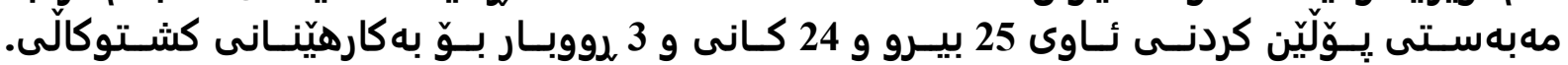

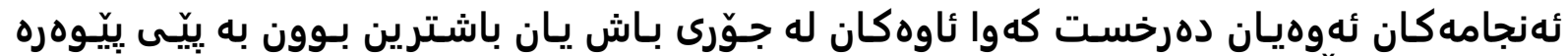

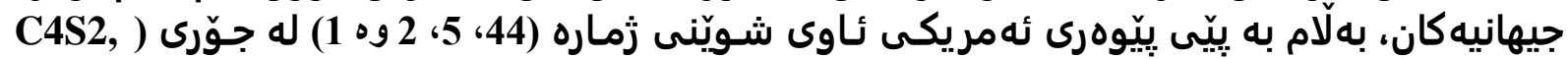

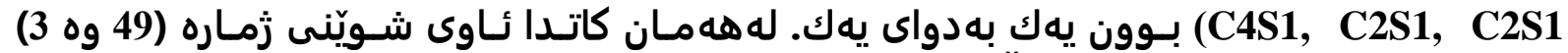

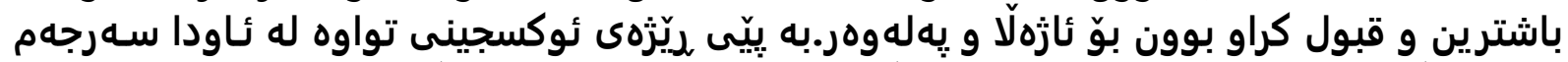

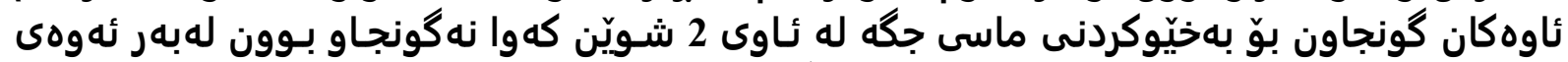

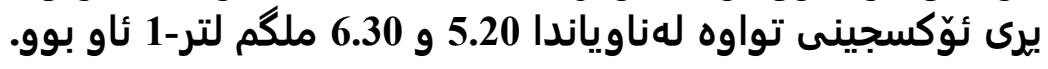

تحديد صلاحية بعض مصادر المياه للاستخدامات الزراعية في المنطقة رانية| محافظة السليمانية.

الخلاصة

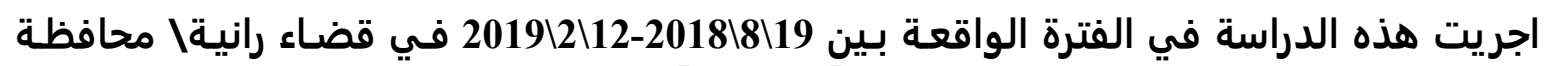

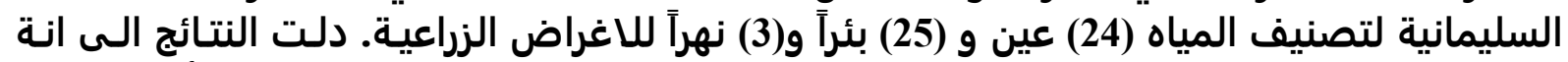

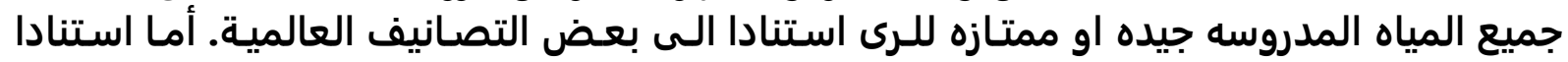

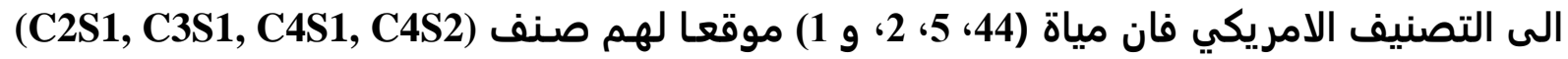

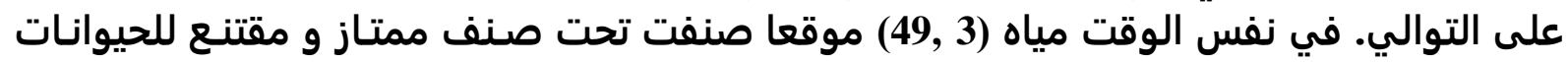

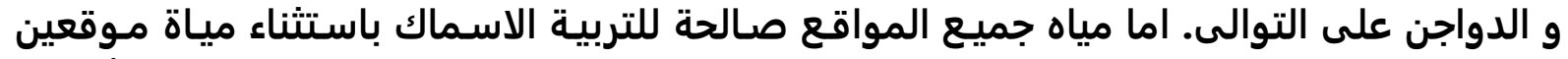

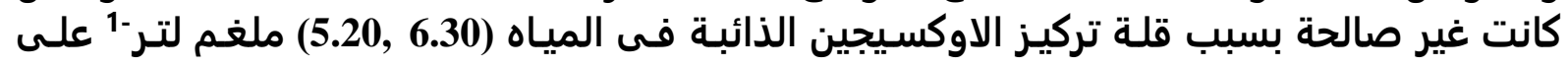
التوالي. 